\title{
F-Box/WD Repeat-Containing Protein 4
}

National Cancer Institute

\section{Source}

National Cancer Institute. F-Box/WD Repeat-Containing Protein 4. NCI Thesaurus. Code C75416.

F-box/WD repeat-containing protein 4 ( $412 \mathrm{aa}, \sim 46 \mathrm{kDa}$ ) is encoded by the human FBXW4 gene. This protein plays a role in both the modulation of protein turnover and the regulation of limb development. 